\title{
ANALISIS TINDAK TUTUR DALAM INTERAKSI TENTARA KODIM 0409 REJANG LEBONG
}

\author{
Elsa Merdian, Ngudining Rahayu, dan Bambang Djunaidi \\ Program Studi Pendidikan Bahasa Indonsia \\ Jurusan Pendidikan Bahasa dan Seni \\ FKIP Universitas Bengkulu \\ elsawanis42@gmail.com
}

\begin{abstract}
Abstrak
Tujuan penelitian ini adalah untuk mendeskripsikan wujud jenis tindak tutur yang terdapat dalam interaksi tentara KODIM 0409 Rejang Lebong. Metode dalam penelitian ini adalah metode deskriptif. Data penelitian ini berupa tindak tutur ilokusi interaksi tentara KODIM 0409 Rejang Lebong. Sumber data penelitian ini adalah tuturan lisan dalam interaksi tentara KODIM 0409 Rejang Lebong. Teknik pengumpulan data menggunakan metode observasi, catatan lapangan, dan perekaman. Teknik analisis data dalam penelitian ini dilakukan melalui langkah-langkah yaitu: (1) mentranskripsikan data (2) mereduksi data, (3) mengklasifikasikan data, (4) menginterpretasi data, dan (5) menyimpulkan hasil analisis. Hasil penelitian ditemukan total keseluruhan 365 tuturan diantranya ilokusi asertif sebanyak (217 tuturan) yang terdiri atas yaitu: tindak menyatakan (59 tuturan), melaporkan (1 tuturan), memberitahukan (127 tuturan), mengeluh (7 tuturan), menegaskan ( 2 tuturan), dan membanggakan (1 tuturan). Tuturan jenis direktif ditemukan pertanyaan (112 tuturan), tindak memerintah/ menyuruh (6 tuturan), meminta (8 tuturan), menasihatkan (1 tuturan), menyarankan ( 6 tuturan), dan menganjurkan (3 tuturan). Tuturan jenis ekspresif yang ditemukan yaitu ekspresif memuji (1 tuturan) dan mengucapkan terima kasih (6 tuturan). Tuturan komisif yang ditemukan yaitu tindak penolakan (1 tuturan) dan tindak menawarkan ( 2 tuturan). Selain itu, jenis tuturan yang ditemukan yaitu deklarasi berupa tindak mengizinkan (1 tuturan) dan memutuskan (1 tuturan). Berdasarkan hasil kesimpulan makna yang terdapat pada tindak tutur dalam interaksi Tentara KODIM 0409 Rejang Lebong yaitu tindak tutur asertif menyampaikan informasi, tindak tutur direktif supaya mitra tutur melakukan apa yang dituturkan oleh penutur, tindak tutur komisif meyakinkan mitra tutur apa yang dituturkan oleh penutur, tindak tutur ekspresif mengungkapkan apa yang dirasakan penutur dan tindak tutur deklarasi memiliki makna pemahaman atau kesepakatan yang sama antara penutur dan mitra tutur.
\end{abstract}

Kata Kunci: Tindak tutur, Interaksi Tentara, KODIM 0409 Rejang Lebong

\begin{abstract}
The purpose of this research was describe the kind of speech act that exist in the interaction of soldiers KODIM 0409 Rejang Lebong. The method of this research was descriptive method. The research of data was the illucoution speech act of soldiers KODIM
\end{abstract}


0409 Rejang Lebong. The data sources of this research was all of speech acts in the interaction of soldiers KODIM 0409 Rejang Lebong. The technique of collecting data used observation, field notes and recording. The technique of analyzing data in this research did by the several steps. They were: (1) trancripting data, reducting data, classifing data, interpreting data, and concluding data, interpreting data, and concluding data. That result found that the total of 365 speech such asertive was (217 speech) that divided into: explaining 59 speech, reporting 1, informing 127, complaining 7, clarifying 2, and boasting 1. The kind of directive speech found that questioning 112, ordering 6, asking 8, advising 1, suggesting 6, and recommending 3. The kind of expressive found that praise expressive 1 and giving thankful 6. The comisive speech that found that was declaration for allowing act 1 and deciding act 1 . The conclusions were the meaning that exist for the speech act in the interaction of soldierss KODIM 0409 Rejang Lebong consists of sertibe speech acts to deliver the information, directive speech act the speaker did what the another speaker, comisive speech act to make sure the speaker what the another speaker speech, expressive speech act to express what the speaker act 1 and offering act 2. Beside that, the kind of of speech act found that was declaration for allowing act 1 and deciding act 1 . The conclusions were the meaning that exist for the speech act in the interaction of soldiers KODIM 0409 Rejang Lebong consists of asertibe speech acts to deliver the information, directive speech act the speaker did what the another speaker, comisive speech act to make sure the speaker what the another speaker speech, expressive speech act to express what the speaker feel and declaration speech act has meaning or dealing between the speaker ans speaker's partner.

\section{Keyword: Speech Act, soldier Interaction, KODIM 0409 Rejang Lebong}

\section{PENDAHULUAN}

Fungsi bahasa sangat penting bagi komunikasi dan interaksi sesama manusia. Menurut Chaer dan Agustine (2010:14) fungsi bahasa adalah alat untuk berinteraksi atau alat untuk berkomunikasi dalam arti, alat untuk menyampaikan pikiran, gagasan, konsep, atau juga perasaan. Melalui komunikasi pasti penutur ingin menyampaikan tujuan atau maksud kepada mitra tutur secara jelas. Untuk itu penyampaian maksud dan tujuan harus efektif dan efisien, sehingga pesan yang ingin disampaikan dapat dipahami dengan jelas oleh mitra tutur yang terlibat dalam proses komunikasi. Proses komunikasi yang efektif dan efisien tidak akan terjadi dengan baik apabila bahasa yang disampaikan oleh penutur tidak dipahami oleh mitra tutur. Dalam kegiatan berinteraksi dan berkomunikasi terdapat peristiwa tutur, tuturan, dan tindak tutur. Tindak tutur dan peristiwa tutur merupakan dua gejala yang terdapat pada suatu proses komunikasi dalam menyampaikan suatu maksud dari penutur.

Tindak tutur merupakan bagian dari studi pragmatik. Menurut Lavinson (dalam Suyono, 1990:2) pragmatik adalah kajian tentang kemampuan pemakaian bahasa untuk mengaitkan kalimat-kalimat dengan konteks penggunaan kalimat itu. Sejalan dengan itu menurut Yule (2006:5) bahwa pragmatik adalah studi tentang hubungan 
anatara bentuk-bentuk linguistik dan pemakai bentuk-bentuk itu. Kajian pragmatik mengenai pemakaian bahasa yang sesuai dengan konteks diantaranya yaitu tindak tutur. Untuk mencapainya diperlukan konteks situasi komunikasi.

Bahasa dan konteks merupakan dua hal yang tidak dapat dipisahkan karena memiliki kaitan yang erat. Bahasa memerlukan konteks untuk menjelaskan maksud dan maknanya, sedangkan konteks akan memiliki makna jika terdapat tindak berbahasa di dalamnya. Karena konteks dalam hal ini berfungsi sebagai pertimbangan dalam mendeskripsikan makna tuturan dan penggunaan bahasa dalam komunikasi. Untuk itu penutur harus memilih bahasa yang tepat untuk disampaikan kepada mitra tutur agar maksud dan keinginan penutur bisa tersampaikan dan dimengerti oleh mitra tutur.

Salah satu kegiatan interaksi yang terjadi dalam kegiatan komunikasi terdapat pada TNI AD KODIM 0409 Rejang Lebong. TNI sebagai alat negara di bidang pertahanan memiliki tugas yang harus diemban. Sesuai dengan Undang-Undang Nomor. 34 tahun 2004 tentang TNI pasal 7 ayat (1), tugas pokok TNI adalah menegakkan kedaulatan negara, mempertahankan keutuhan wilayah Negara Kesatuan Republik Indonesia yang berdasarkan Pancasila dan Undang-Undang Dasar Republik Indonesia Tahun 1945, serta melindungi segenap bangsa dan seluruh tumpah darah Indoensia dari ancaman dan gangguan terhadap keutuhan bangsa dan negara.

Sebagai instansi militer tentara KODIM 0409 Rejang Lebong mempunyai ragam bahasa yang berbeda dengan instansi atau kelompok lain. Ragam bahasa tersebut dipengaruhi oleh sikap dan watak tentara yang mempunyai karakter tegas dan disiplin baik di dalam maupun di luar kantor. Selain itu ragam bahasa yang digunakan juga dipengaruhi oleh konteks, topik, tempat, siatuasi, tujuann, isi, cara bertutur, dan juga lawan tutur.

Interaksi yang dilakukan anggota TNI AD KODIM 0409 menggunakan bahasa dalam kegiatan berkomunikasi baik di dalam maupun di luar instansi. Interaksi yang terdapat dalam tentara KODIM 0409 Rejang Lebong yaitu hubungan timbal balik antara dua orang tentara atau lebih dan masingmasing yang terlibat di dalamnya. Dalam interaksi tentara di KODIM 0409 Rejang Lebong terdapat tindak tutur ketika berkomunikasi. Peristiwa berlangsungnya interaksi pada tentara di KODIM 0409 Rejang Lebong mempunyai tuturan yang beragam, sesuai dengan konteksnya. Tuturan tersebut digunakan untuk menyampaikan informasi, pernyataan, dan ekspresi rasa senang, marah, kesal, dan simpati setiap individu.

Tentara yang ada di KODIM mempunyai latar belakang yang berbeda setiap individunya baik dari segi kedudukan, maupun dari segi latar belakang hidupnya. Jadi, setiap individu mempunyai kedudukan, tugas, dan cara dalam menjalani kegiatannya sehari-hari di lingkungan KODIM. Hal ini membuat bentuk interaksi yang terjadi akan beragam dan mempunyai bentuk berbedabeda. Sehingga dalam interaksi tersebut akan terbentuk tindak tutur yang bermacammacam pula.

Interaksi yang terjadi di tentara KODIM 0409 terjadi dengan konteks pembicaraan yang berbeda-beda. Misalnya interaksi yang terjadi antara staf Intelijen dengan seorang anak yang ingin membuat SKBD. Dalam interaksi tersebut bahasa yang digunakan oleh tentara dan anak tersebut mungkin berbeda dengan bahasa yang digunakan oleh staf lainnya. Hal ini dipengaruhi oleh konteks pembicaraan tersebut. Bahasa yang digunakan tersebut antara lain dipengaruhi 
oleh siapa penutur dan siapa mitra tutur, tujuan pembicaraan, topik pembicaraan, tempat dan situasi atau kondisi, serta jenis pembicaraan. Semuanya itu mepengaruhi bahasa yang digunakan ketika berinteraksi.

Tindak tutur dalam interaksi tentara KODIM 0409 merupakan salah satu bentuk pemakaian bahasa yang sesuai dengan topik pembicaraan, tujuan pembicaraan, situasi dan tempat berlangsungnya pembicaraan tersebut. Menurut Chaer dan Agustine (2010: 50) tindak tutur merupakan gejala individual, bersifat psikologis, dan keberlangsungannya ditentukan oleh kemampuan bahasa di penutur dalam menghadapi situasi tertentu. Penggunaan bahasa dalam berinteraksi pada tentara KODIM 0409 merupakan salah satu bentuk komunikasi. Melalui proses komunikasi akan memunculkan peristiwa tindak tutur. Tindak tutur dan peristiwa tutur merupakan dua gejala yang terdapat pada suatu proses, yakni proses komunikasi.

Dalam usaha untuk mengungkapkan diri mereka, orang-orang tidak hanya menghasilkan tuturan yang mengandung kata-kata dan struktur-struktur gramatikal saja, tetapi mereka juga memperlihatkan tindakan-tindakan melalui tuturan-tuturan itu. Tindakan-tindakan yang ditampilkan lewat tuturan biasanya disebut tindak tutur (Yule, 1996: 82). Berkenaan dengan tuturan tersebut, tindak tutur yang dilangsungkan dalam kalimat performatif oleh Austin (dalam Chaer 2010:53) menyatakan sebagai tiga peristiwa tindakan yang berlangsung sekaligus yaitu tindak tutur lokusi atau locutionary act, tindak tutur ilokusi atau ilocutionary act, dan tindak tutur perlokusi atau perlocutionary act.

Menurut Nadar (2013: 14) tindak tutur ilokusi adalah apa yang ingin dicapai oleh penutur pada waktu menuturkan sesuatu dan dapat merupakan tindakan menyatakan, berjanji, meminta maaf, mengancam, meramalkan, memerintah, meminta, dan lain-lain. Tindak ilokusi dapat dikatakan sebagai tindak terpenting dalam kajian dan pemahaman tindak tutur.

Berkaitan dengan tindak tutur ilokusi, Searle (dalam Tarigan, 1986:47) teori tindak ilokusi dibagi menjadi 5 bagian yaitu:

(1) Asertif

llokusi ini melibatkan pembicara pada kebenaran proposisi yang diekspresikan, misalnya: menyatakan, memberitahukan, menyarankan, membanggakan, mengeluh, menuntut, melaporkan.

(2) Direktif

Tindak tutur direktif dimaksudkan untuk menimbulkan beberapa efek melalui tindakan sang menyimak, misalnya: memesan, memerintahkan, memohon, meminta, menyarankan, menganjurkan, menasihatkan.

(3) Komisif

Tindak tutur komisif melibatkan pembicaraan pada beberapa tindakan yang akan datang, misalnya: menjanjikan, bersumpah, menawarkan, memanjatkan (doa).

(4) Ekspresif

Tindak tutur ekspresif mempunyai fungsi untuk mengekspresikan mengungkapkan, atau memberitahukan sikap psikologis sang pembicara menuju suatu pernyataan keadaan yang diperkirakan oleh ilokusi; misalnya: mengucapkan terima kasih, mengucapkan selamat, memaafkan, mengampuni, menyalahkan, memuji, menyatakan belasungkawa, dan sebagainya.

(5) Deklarasi

Tindak tutur deklaratif adalah ilokusi yang bila performasinya berhasil akan menyebabkan korespondensi yang baik antara isi proposisional dengan realitas; contoh: menyerahkan diri, memecat, 
membebaskan, membaptis, memberi nama, menamai, mengucilkan, mengangkat, menunjuk, menentukan, menjatuhkan hukuman, memvonis, dan sebagainya.

Hal tersebut menjadi salah satu alasan penulis tertarik melakukan penelitian terhadap analisis tindak tutur dalam interaksi tentara KODIM 0409 Rejang Lebong. Jadi, perlu dirumuskan suatu masalah penelitian bagaimana bentuk-bentuk dan makna tindak tutur ilokusi yang terjadi dalam interaksi tentara KODIM 0409 Rejang Lebong.

\section{METODE}

Metode yang digunakan dalam penelitian ini adalah metode deskriptif. Data dalam penelitian ini berupa tuturan yang mengandung tindak tutur ilokusi dalam interaksi tentara dengan tentara KODIM 0409 Rejang Lebong dan percakapan tentara KODIM 0409 Rejang Lebong dengan masyarakat sipil yang berkepentingan. Sumber data dalam penelitian ini adalah semua tuturan lisan yang ada dalam interaksi tentara KODIM 0409 Rejang Lebong selama 1,5 bulan, dari tanggal 28 Mei s.d. 16 Juli 2018. Teknik pengumpulan data menggunakan teknik pengamatan/ observasi, catatan lapangan, dan perekeman. Langkah-langkah analisis data dalam penelitian: 1) menstranskripsikan data, 2) mengidentifikasikan data, 3) mengklasifikasikan data, 4) menginterpretasikan data, dan 5) menyimpulkan hasil analisis.

\section{HASIL PENELITIAN DAN PEMBAHASAN Hasil}

Berdasarkan penelitian yang telah dilakukan mengenai analisis tindak tutur dalam imteraksi tentara KODIM 0409 Rejang Lebong diperoleh tindak tutur pertama yang pada tuturan ilokusi asertif ditemukan data sebanyak 217 tuturan di antaranya terdiri dari tindak asertif menyatakan sebanyak 59 tuturan atau 16,16 persen dari total keseluruhan yang mempunyai variasi yaitu: menyatakan informasi, menyatakan pendapat dan menyatakan respons. Terdapat juga tindak asertif melaporkan informasi sebanyak 1 tuturan atau 0,27 persen dari total keseluruhan, asertif memberitahukan sebanyak 127 tuturan atau 34,79 persen dari total keseluruhan. Selain itu, terdapat jenis tindak tutur ilokusi asertif menegaskan sebanyak 22 tuturan atau 6,02 persen dari total keseluruhan, asertif mengeluh sebanyak 7 tuturan atau 1,91 persen dari total keseluruhan dan 1 tuturan atau 0,27 persen dari total keseluruhan berupa asertif membanggakan. Jadi, total tindak tutur asertif yang ditemukan sebanyak 217 data dari total 365 tuturan atau sebesar 59,15 persen dari total 100 persen.

Tindak tutur yang kedua yang ditemukan tindak tutur ilokusi direktif sebanyak 136 tuturan diantaranya terdiri dari 112 tuturan atau 30,68 persen dari total keseluruhan berupa pertanyaan, 6 tuturan atau 1,64 persen dari total keseluruhan berupa memerintah, 6 tuturan atau 1,64 persen dari total keseluruhan berupa menyarankan, 1 tuturan atau 0,27 persen dari total keseluruhan berupa menasihatkan, 3 tuturan atau 0,82 persen dari total keseluruhan berupa menganjurkan, 1 tuturan atau 0,27 persen dari total keseluruhan mengizinkan dan 8 tuturan atau 2,19 persen dari total keseluruhan berupa meminta. Jadi, total tindak tutur direktif yang ditemukan sebanyak 136 tuturan atau sebesar 37,51 persen dari total 100 persen.

Tindak tutur yang ketiga yang ditemukan tindak tutur ilokusi ekspresif sebanyak 7 tuturan diantaranya terdiri meliputi 1 tuturan atau 0,27 persen dari total 
keseluruhan berupa memuji dan 6 tuturan atau 1,64 persen dari total keseluruhan berupa mengucapkan terima kasih. Jadi, total tindak tutur ekspresif yang ditemukan sebanyak 7 tuturan data dari total 365 tuturan atau sebesar 1,91 persen dari total 100 persen.

Tindak tutur yang keempat yang ditemukan tindak tutur ilokusi jenis tindak tutur ilokusi komisif sebanyak 3 tuturan meliputi 1 tuturan atau 0,27 persen dari total keseluruhan penolakan dan 2 tuturan atau 0,54 persen dari total keseluruhan menawarkan. Jadi, total tindak tutur komisif yang ditemukan sebanyak 3 tuturan data dari total 365 tuturan atau sebesar 0,81 persen dari total 100 persen.

Tindak tutur yang kelima yang ditemukan tindak tutur ilokusi deklarasi ditemukan berupa 1 tuturan atau 0,27 persen dari total keseluruhan memutuskan. Jadi, total tindak tutur deklarasi sebanyak 1 tuturan data dari total 365 tuturan atau sebesar 0,27 persen dari total 100 persen.

\section{Pembahasan}

Tindakan-tindakan yang ditampilkan lewat tuturan biasanya disebut tindak tutur (Yule, 1996: 82). Sejalan dengan pendapat tersebut, Tarigan (1986: 33) mengemukakan telaah mengenai bagaimana cara kita melakukan sesuatu dengan memanfaatkan kalimat-kalimat adalah telaah mengenai tindak ujar (speech acts). Dalam menelaah tindak ujar ini kita harus menyadari benarbenar betapa pentingnya konteks ucapan/ungkapan.

Konteks di dalam interaksi Tentara KODIM 0409 Rejang Lebong terdapat penutur dan mitra tutur yang berbeda-beda karena setiap tuturan memiliki topik yang berbeda sehingga konteks yang terikat akan berbeda. Oleh karena itu, tuturan ilokusi dalam interaksi Tentara KODIM 0409 Rejang
Lebong mempunyai topik pembicaraan yang bervariasi di setiap staf yang berbeda karena disesuaikan dengan situasi dan koteks.

Proses tuturan di dalam interaksi Tentara KODIM 0409 Rejang Lebong ini terdapat tindak tutur ilokusi asertif, direktif, ekspresif, komisif, dan deklarasi. Menurut Yule (1996:92) bahwa representatif (asertif) ialah jenis tindak tutur yang menyatakan apa yang diyakini penutur kasus atau bukan. Misalnya pernyataan suatu suatu fakta, penegasan, kesimpulan, menyatakan, mengeluh, dan pendeskripsian.

Berdasarkan hasil penelitian, tuturan ilokusi asertif ditemukan data sebanyak 217 tuturan di antaranya terdiri dari tindak asertif menyatakan sebanyak 59 tuturan atau 16,16 persen dari total keseluruhan yang mempunyai variasi yaitu: menyatakan informasi, menyatakan pendapat dan menyatakan respons. Terdapat juga tindak asertif melaporkan informasi sebanyak 1 tuturan atau 0,27 persen dari total keseluruhan, asertif memberitahukan sebanyak 127 tuturan atau 34,79 persen dari total keseluruhan. Selain itu, terdapat jenis tindak tutur ilokusi asertif menegaskan sebanyak 22 tuturan atau 6,02 persen dari total keseluruhan, asertif mengeluh sebanyak 7 tuturan atau 1,91 persen dari total keseluruhan dan 1 tuturan atau 0,27 persen dari total keseluruhan berupa asertif membanggakan. Jadi, total tindak tutur asertif yang ditemukan sebanyak 217 data dari total 365 tuturan atau sebesar 59,15 persen dari total 100 persen. Berdasarkn hasil penelitian yang telah dilakukan, pada tuturan di dalam interaksi Tentara KODIM 0409 Rejang Lebong, tidak menemukan tindak menyarankan, menuntut, pendeskripsian, dan kesimpulan.

Masih menurut Yule (1996:93) tuturan direktif ialah jenis tindak tutur yang dipakai oleh penutur untuk menyuruh orang lain 
melakukan sesuatu. Tuturan ini meliputi tindak perintah, pemesanan, permohonan, pemberian saran, memesan, meminta, mermerintah, menganjurkan, dan menasihati. Pada hasil penelitian ditemukan tindak pertanyaan ada 112 tuturan atau 30,68 persen dari total keseluruhan berupa pertanyaan, 6 tuturan atau 1,64 persen dari total keseluruhan berupa memerintah, 6 tuturan atau 1,64 persen dari total keseluruhan berupa menyarankan, 1 tuturan atau 0,27 persen dari total keseluruhan berupa menasihatkan, 3 tuturan atau 0,82 persen dari total keseluruhan berupa menganjurkan, 1 tuturan atau 0,27 persen dari total keseluruhan berupa mengizinkan dan 8 tuturan atau 2,19 persen dari total keseluruhan berupa meminta. Jadi, total tindak tutur direktif yang ditemukan sebanyak 136 tuturan atau sebesar 37,51 persen dari total 100 persen. Berdasarkan hasil penelitian yang telah dilakukan, pada tuturan di dalam interaksi Tentara KODIM 0409 Rejang Lebong, tidak menemukan tindak memesan, melarang, dan memohon.

Jenis tuturan lainnya yaitu tindak tutur komisif. Yule (1996: 94) mengatakan bahwa tindak tutur komisif ialah jenis tindak tutur yang dipahami oleh penutur untuk mengikatkan dirinya terhadap tindakantindakan di masa yang akan datang. Tindak tutur ini menyatakan apa saja yang dimaksudkan oleh penutur. Tindak tutur ini dapat berupa; janji, ancaman, penolakan, ikrar. Pada hasil penelitian ditemukan tindak penolakan ada 1 tuturan atau 0,27 persen dari total keseluruhan penolakan dan 2 tuturan atau 0,54 persen dari total keseluruhan menawarkan. Jadi, total tindak tutur komisif yang ditemukan sebanyak 3 tuturan data dari total 365 tuturan atau sebesar 0,81 persen dari total 100 persen. Berdasarkan hasil penelitian yang telah dilakukan, pada tuturan di dalam interaksi
Tentara KODIM 0409 Rejang Lebong, tidak menemukan tindak ancaman, ikrar, dan janji.

$$
\text { Selanjutnya, Yule }
$$

berpendapat bahwa ekspresif ialah jenis tindak tutur yang menyatakan sesuatu yang dirasakan oleh penutur. Tindak tutur ini mencerminkan pernyataan-pernyataan psikologis dan dapat berupa pernyataan kegembiraan, kesulitan, kesukaan, kebencian, kesenangan, atau kesengsaraan, mengucapkan terima kasih, mengucapkan selamat, memaafkan, mengampuni, menyalahkan, memuji, dan sebagainya. Pada hasil penelitian ditemukan tindak memuji 1 tuturan atau 0,27 persen dari total keseluruhan berupa memuji dan 6 tuturan atau 1,64 persen dari total keseluruhan berupa mengucapkan terima kasih. Jadi, total tindak tutur ekspresif yang ditemukan sebanyak 7 tuturan data dari total 365 tuturan atau sebesar 1,91 persen dari total 100 persen. Berdasarkan hasil penelitian yang telah dilakukan, pada tuturan di dalam interaksi Tentara KODIM 0409 Rejang Lebong, tidak ditemukan tindak mengucapkan selamat, memaafkan, mengampuni, dan menyalahkan.

Tindak tutur yang terkahir adalah tindak tutur deklarasi. Menurut Searle (dalam Rahardi: 2009: 18) mengatakan bahwa tindak tutur deklarasi bukan deklaratif adalah bentuk tutur yang berhubungan antara isi tuturan dengan kenyataan seperti berpasarah, memecat, memutuskan, membaptis, memberi nama, mengangkat, mengucilkan, dan menghukum.

Berdasarkan hasil penelitian yang telah dilakukan mengenai tindak tutur dalam interaksi Tentara KODIM 0409 Rejang Lebong, ditemukan tindak tutur ilokusi deklarasi berupa 1 tuturan atau 0,27 persen dari total keseluruhan memutuskan. Jadi, total tindak tutur deklarasi sebanyak 1 tuturan data dari total 365 tuturan atau 
sebesar 0,27 persen dari total 100 persen. Dalam tindak tutur deklarasi tidak ditemukan tindak menyerahkan diri, memecat, membebaskan, menjatuhkan hukuman, membaptis, memecat, mengucilkan, memberi nama, menjatuhkan hukuman dan menentukan.

Tuturan ilokusi dalam Interaksi Tentara KODIM 0409 Rejang Lebong memiliki lima tindak tutur ilokusi yaitu asertif, dierktif, komisif, ekspresif, dan deklarasi yang terjadi disetiap konteks yang berbeda diantaranya di ruangan intelijen, personalia, operasional, teritorial, logistik, dan koperasi. Pada interaksi Tentara KODIM 0409 Rejang Lebong mempunyai Penutur-penutur dan mitra tutur yang berbeda-beda karena pada setiap konteks dan situasi penutur-mitra tutur tidak sama penuturnya. Karena setiap staf yang ada di KODIM 0409 Rejang Lebong memiliki anggota yang berbeda pada setiap stafnya.

Tuturan ilokusi dalam interaksi Tentara KODIM 0409 Rejang Lebong mempunyai tuturan yang tegas dan jelas pada saat atasannya memberikan pengarahan atau perintah kepada bawahannya. Ragam bahasanya bisa menggunakan Bahasa Indonesia dan bahasa daerah seperti bahasa Bengkulu.

Tuturan yang digunakan dalam interaksi Tentara KODIM 0409 Rejang Lebong memiliki topik pembicaraan yang berbeda dengan instansi lainnya dan bervariasi di setiap staf yang berbeda-beda diantaranya di staf intelijen membicarakan tentang pembuatan SKBD, pengamanan HUT Rejang Lebong dan sejanta, pada staf teritorial membicarakan tentang tunjangan Babinsa, pendidikan TNI, tunjangan kinerja, dan membantu membuat laporan geladi posko, pada staf personalia membicarakan tentang Kasdim KODIM 0409 Rejang Lebong, pada staf operasional membicarakan tentang pemilihan pelatih PBB untuk melatih siswa disekolah, pada staf logistik membicarakan tentang persiapan geladi posko, sedangkan pada staf koperasi memiliki topik pembicaraan pada jual beli, usifa, serta peminjaman uang di koperasi untuk para anggota TNI KODIM 0409 Rejang Lebong.

Makna yang terdapat pada tindak tutur dalam interaksi Tentara KODIM 0409 Rejang Lebong diantaranya tindak tutur asertif. Tindak tutur ini memiliki makna menyampaikan informasi. Adapun, tindak tutur direktif memiliki makna supaya mitra tutur melakukan apa yang dituturkan oleh mitra tutur, sedangkan tindak tutur komisif memiliki makna kesediaan mitra tutur apa yang dituturkan oleh penutur, dan tindak tutur ekspresif memiliki makna mengungkapkan apa yang dirasakan penutur dan tindak tutur deklarasi memiliki makna pemahaman atau kesepakatan yang sama antara peenutur dan mitra tutur.

Berdasarkan hasil penelitian, tindak tutur interaksi Tentara KODIM 0409 Rejang Lebong memiliki hal yang unik karena atasan memberikan perintah secara langsung tegas, tidak bertele-tele dan jelas kepada bawahannya. Tetapi, pada saat memberi perintah sesama anggota tentara dilakukan secara tidak langsung. Kemudian, pada tindak tutur ketika bawahannya melaporkan sesuatu kepada atasannya dilakukan secara langsung dan jelas dan tidak bertele-tele. Dalam tindak tutur interaksi Tentara KODIM 0409 Rejang Lebong yang paling banyak dituturkan yaitu tuturan pemberitahuan dan pertanyaan, sedangkan yang paling sedikit dituturkan yaitu komisif, ekspresif dan deklarasi. 


\section{PENUTUP}

Kesimpulan

Berdasarkan penelitian yang telah dilakukan mengenai tindak tutur ilokusi dalam interaksi Tentara KODIM 0409 Rejang Lebong dapat disimpulkan bahwa tindak tutur yang ditemukan berupa tindak tutur ilokusi yaitu asertif, dierktif, komisif, ekspresif, dan deklarasi.

Beberapa bentuk tuturan ilokusi yang ada di KODIM 0409 Rejang Lebong sebagai berikut:

a. Tuturan asertif dalam interaksi Tentara KODIM 0409 Rejang Lebong menyatakan apa yang diyakini penutur.

b. Tuturan direktif dalam interaksi Tentara KODIM 0409 Rejang Lebong dimaksudkan untuk menimbulkan efek melalui tindakan sang penyimak.

c. Tuturan komisif dalam interaksi Tentara KODIM 0409 Rejang Lebong melibatkan pembicaraan.

d. Tuturan ekspresif dalam interaksi Tentara KODIM 0409 Rejang Lebong untuk mengekspresikan atau mengungkapakan sikap penutur kepada mitra tutur.

e. Tuturan deklarasi dalam interaksi Tentara KODIM 0409 Rejang Lebong menggunakan bahasa yang lugas.

Makna yang terdapat pada tindak tutur dalam interaksi Tentara KODIM 0409 Rejang Lebong yaitu:

a. Tindak tutur asertif memiliki makna menyampaikan informasi.

b. Tindak tutur direktif memiliki makna supaya mitra tutur melakukan apa yang dituturkan oleh penutur. c. Tindak tutur komisif memiliki makna kesediaan atau meyakinkan mitra tutur apa yang dituturkan oleh penutur.

d. Tindak tutur ekspresif memiliki makna mengungkapkan apa yang dirasakan penutur.

e. Tindak tutur deklarasi memiliki makna pemahaman atau kesepakatan yang sama antara penutur dan mitra tutur.

\section{Saran}

Penulis mengharapkan ada penelitian bandingan mengenai tindak tutur pada interaksi tentara KODIM lainnya sehingga dapat ditemukan variasi tuturan yang berbeda yang tidak ditemukan dalam intekasi Tentara KODIM 0409 Rejang Lebong serta keunikan lain dari interaksi tentara lainnya.

\section{DAFTAR PUSTAKA}

Chaer, Abdul dan Leonie Agustina. 2010. Sosiolinguistik. Jakarta: Rineka Cipta.

Instrumen HAM Nasional. Tematik HAM. UU Nomor 2004 tentang Tentara Nasional Indonesia.

Nadar, F.X. 2013. Pragmatik \&Penelitian Pragmatik. Yogyakarta: Graha IImu.

Suyono. 1990. Pragmatik Dasar-Dasar dan Pengajarannya. Malang: Yayasan Asih Asah Asuh.

Tarigan, Henry Guntur. 1986. Pengajaran Pragmatik. Bandung: ANGKASA.

Undang-undang No. 34 Tahun 2004 Pasal 7 Ayat 1 Tentang Tugas Pokok TNI.

Yule, George. 1996. Pragmatik. Diterjemahkan Indah Fajar Wahyuni. Yogyakarta: Pustaka Pelajar. 